\title{
Growth and Diversity of the Population of the Soviet Union
}

\author{
By BARBARA A. ANDERSON and BRIAN D. SILVER
}

\begin{abstract}
The most remarkable feature of the Soviet Union's demography is its ethnic diversity. More than 90 ethnic groups are indigenous to the territory of the Soviet Union. Ethnic Russians composed only 50.8 percent of the population according to preliminary 1989 census results. The article examines official Soviet statistics for the period 1959 to 1989 to illustrate some of the risks in describing Soviet demographic behavior. Is fertility in the Soviet Union high or low? Answer: both. Is the Soviet population growing rapidly or slowly? Answer: both. The changing ethnic composition of the population of the USSR as a whole reflects large differences in growth rates of ethnic groups; the changing composition of the USSR by region also reflects differences in migration by ethnic group. Differences in growth rates are reshaping the ethnic composition of the Soviet labor force. For the USSR as a whole between 1979 and 1989, three-fourths of the net increment to the working ages was contributed by the one-sixth of the population in 1979 that was traditionally Muslim in religion.
\end{abstract}

Barbara A. Anderson is professor of sociology at the University of Michigan and research scientist and associate director for training at the university's Population Studies Center. She holds a Ph.D. in sociology from Princeton University. She is the author of Internal Migration and Modernization in Late Nineteenth-Century Russia and coauthor of Human Fertility in Russia.

Brian D. Silver is professor and chairperson of the Department of Political Science at Michigan State University and a research affiliate of the Population Studies Center of the University of Michigan. He earned his Ph.D. from the University of Wisconsin. He is coeditor of Soviet Asian Ethnic Frontiers.

NOTE: The authors share equal responsibility for this article. The research was supported by NICHD grant nos. RO1 HD-19915 and P30 HD-10003. 
7 HE Soviet Union has the third-largest population of any country in the world. The 1989 census counted 286.7 million people. ${ }^{1}$ Developments in the Soviet population have been of great interest because of its size and because of the importance of the Soviet Union in world affairs. In addition, reports of unfavorable demographic features of the Soviet population, such as high rates of infant mortality and adult mortality, have been cited within the country and abroad as evidence of the low quality of life in the Soviet Union compared to other industrial countries. The infant mortality rate, for example, was 25.4 infant deaths per 1000 live births in 1987; life expectancy at birth for Soviet males was 65.0 years and for females, 73.8 years, in $1986-87 .^{2}$

1. This is the total of the de facto or present (in Russian, nalichnoe) population in the USSR according to preliminary figures from the 1989 census. The de jure or permanent (postoiannoe) population is 1 million less: 285.7 million. The State Committee on Statistics of the USSR - formerly the Central Statistical Board - has changed the way in which it reports most population data in the censuses. Barbara $A$. Anderson and Brian D. Silver, "Permanent' and 'Present' Populations in Soviet Statistics," Soviet Studies, 37:386-402 (July 1985). Accordingly, unless noted otherwise, all data in this article from the 1959 and 1970 Soviet censuses refer to the present population, and all data from the 1979 and 1989 censuses refer to the permanent population.

2. All of these reported figures are subject to error. Infant deaths appear to be underreported substantially, especially in the regions with high rates; and Soviet definitions of "infant death" and "live birth" differ from those proposed by the World Health Organization. We estimate that the reported infant mortality rates for the Soviet Union need to be inflated by at least 22 percent to make them comparable with World Health Organization definitions. Barbara A. Anderson and Brian D. Silver, "Infant Mortality in the Soviet Union: Regional Differences and Measurement Issues," Population and Development Review, 12:705-38(Dec. 1986). Life expectancy at birth is probably overestimated, due to underreporting of deaths, overstatement of age at death, and overstate-
Perhaps the most remarkable feature of the Soviet Union's demography is not its size or the state of its public health but its ethnic diversity. Members of more than ninety ethnic groups that are indigenous to the territory of the Soviet Union were counted in the 1989 census. Twenty-two ethnic groups - "nationalities," in common Soviet usage - had populations of 1 million or more. Ethnic Russians composed 50.8 percent of the population in 1989 and they will fall below 50 percent of the Soviet population before the middle of the 1990 s. $^{3}$ In addition to 145 million ethnic Russians in 1989, the Soviet population had 56 million members of other Slavic nationalities, 56 million members of nationalities whose traditional religion is Islam, and another 29 million people who are neither Slavs nor Muslims. Moreover, the Muslim population is growing rapidly. Though comprising only one-sixth of the population of the USSR in 1979, Muslims contributed 50 percent of the increase in the Soviet population between 1979 and 1989.

It should be difficult for observers of the Soviet Union today to ignore the multiethnic character of that country, as the non-Russian nationalities seek greater economic, cultural, and political autonomy, sometimes manifesting their feelings in large-scale public demonstrations. There have been many reported incidents of violence between ethnic groups not only, as might be commonly supposed,

ment of age in Soviet censuses. Idem, "The Changing Shape of Soviet Mortality, 1958-85: An Evaluation of Old and New Evidence," Population Studies, 43:24365 (July 1989).

3. For further discussion of the changing ethnic composition of the Soviet population, see Barbara A. Anderson and Brian D. Silver, "Demographic Sources of the Changing Ethnic Composition of the Soviet Union," Population and Development Review, Dec. 1989, vol. 15. 
between Russians and non-Russians, but also between members of non-Russian nationalities.

But even today one often reads of Soviet public health, Soviet mortality, and Soviet population growth, as if the range of demographic experience in the USSR were small. In this article we highlight the magnitude of the demographic differences associated with the ethnic diversity of the USSR, while describing trends in some of the main indicators of demographic change.

Our analysis is based on official Soviet population statistics. ${ }^{4}$ Although ethnic differences in demographic behavior are very important in the Soviet Union, we cannot conduct our entire analysis on this basis, because very few data by ethnic group have been published. Thus part of our analysis relies on examination of regional patterns. The Soviet Union has a federal political system. Most major types of demographic data are published both for the Soviet Union as a whole and for the 15 major constituent union republics - also known as Soviet Socialist Republics (SSRs) - but not for ethnic groups. The 15 SSRs are listed in Table 1.

The SSRs are the traditional homelands of major ethnic groups. These ethnic groups are the titular nationalities of these regions in the sense that the areas are named after the ethnic group - Kazakhstan after the Kazakhs, Ukraine after the Ukrainians, and so on. But none of the areas is ethnically homogeneous. As shown in Table 1, the percentage of a republic's population that is of the titular nationality

4. These data have appeared in a variety of sources and are based either on Soviet censuses - of $1959,1970,1979$, and 1989 - or on vital registration statistics. The data on ethnic groups for 1989 come from preliminary unpublished official data from the 1989 Soviet census. ranges from a low of 39.5 percent in Kazakhstan to a high of 93.9 percent in Armenia. Consequently, statistics for the SSRs do not reflect only the demographic behavior of the titular nationality. Nevertheless, differences in the behavior of the titular nationalities are the main source of differences in most demographic behaviors of the populations of the SSRs. We shall use demographic statistics on ethnic groups when they are available.

\section{SOVIET DEMOGRAPHIC BEHAVIOR AS A COMPOSITE OF THE BEHAVIOR OF ITS PARTS}

Change in the behavior of a population often reflects different rates of change in different subpopulations. For example, from 1971 to 1976 , the infant mortality rate (IMR) in the Soviet Union rose from 22.9 infant deaths per 1000 live births to 31.4, an increase of 37 percent. This increase was much larger in the rural areas: the IMR in rural areas rose from 24.3 to $37.8-$ an increase of 56 percent - while the IMR in the urban areas increased 24 percent, from 21.6 to 26.7 . By 1987 , the IMR of the country as a whole had fallen to 25.4 ; in the urban areas it was 21.1, and in the rural areas it was 31.5. Thus the only reason the IMR in the USSR as a whole was higher in 1987 than in 1971 is that the rural IMR was higher in 1987 than it had been in 1971 .

Social scientists sometimes use the term "compositional effect" to describe situations in which changes in the behavior of the whole population are a result of changes in the composition of that population rather than changes in the behavior of the constituent parts. For example, if a population consists of two subpopulations, one with a crude birth rate (CBR) of 20 live births per 1000 population and another with a CBR of 40 , then the CBR of the 


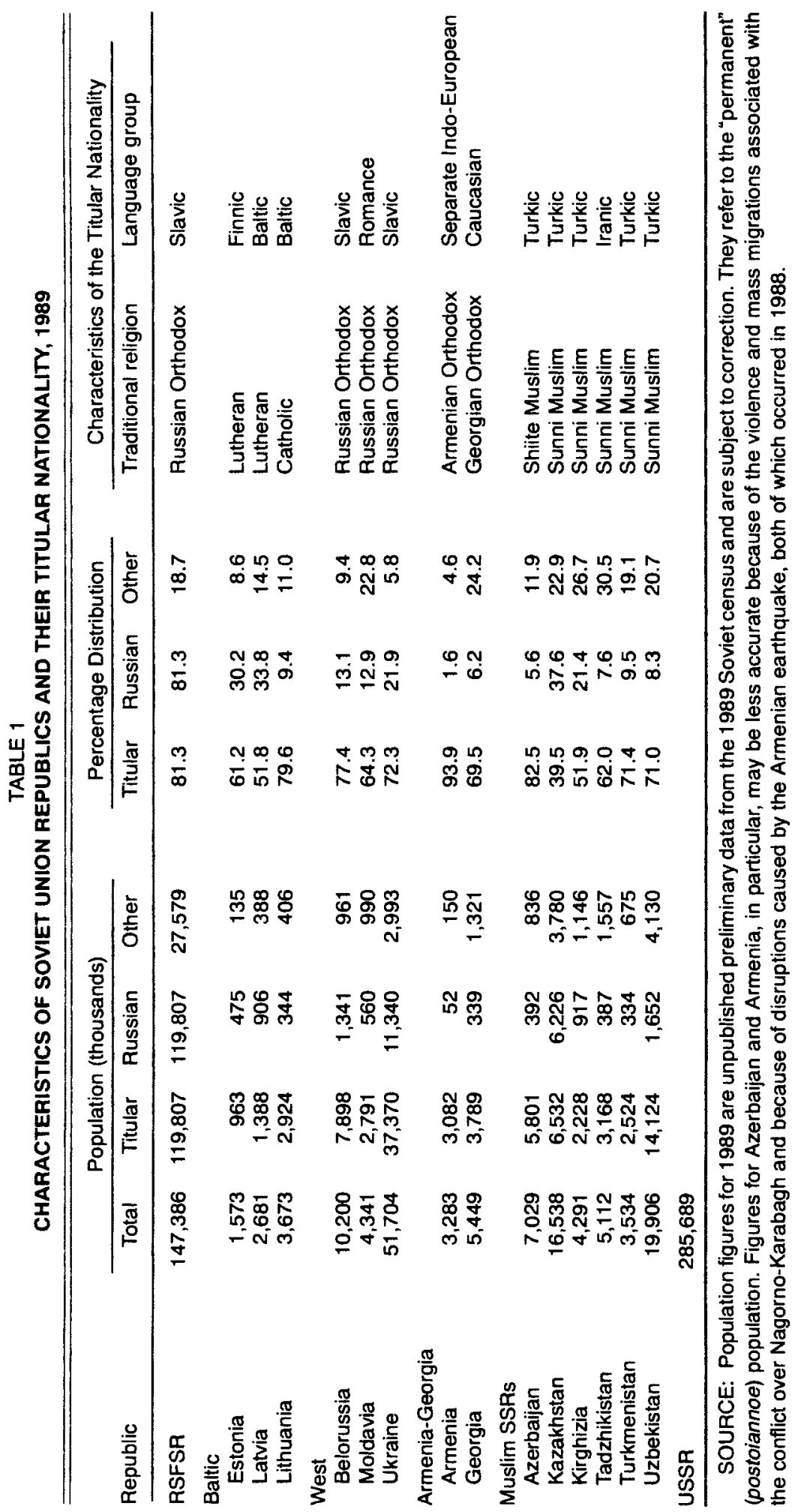


FIGURE 1

PERCENTAGE DISTRIBUTION OF THE SOVIET POPULATION AMONG REGIONS, 1987

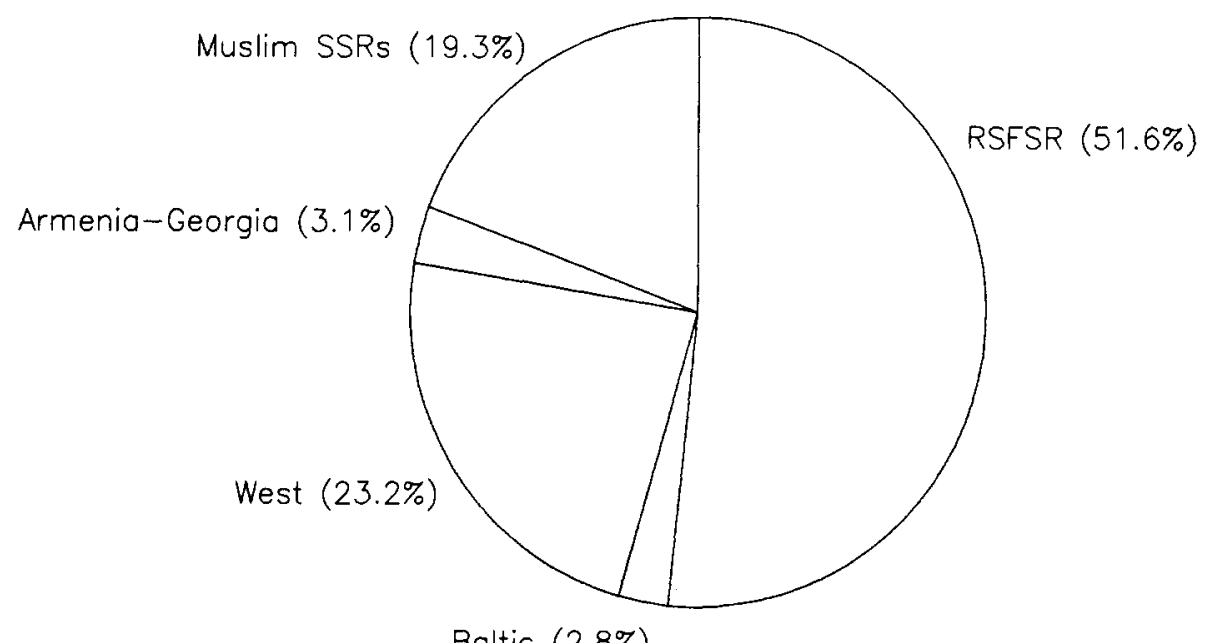

Baltic (2.8\%)

combined population would depend on the distribution of the population between the two groups. The CBR for the entire population would fall somewhere between 20 and 40 . If the shares of the population that belonged to each group changed over time, while the CBRs of each subpopulation remained the same, then the change in the $\mathrm{CBR}$ of the entire population would be a compositional effect.

Of course, in real populations, change in the whole population usually involves both compositional changes and changes in the behavior of the separate subpopulations. In a population as diverse as that of the Soviet Union, the contribution of compositional changes to the changes in statistics for the population as a whole is often very large.

\section{Regional components of}

\section{Soviet demographic behavior}

Let us examine some data on the Soviet population in 1987..$^{5}$ Figure 1 shows the shares of the Soviet population that belong to each of five regional groupings of 15 SSRs: Russia, or the Russian Soviet Federated Socialist Republic (RSFSR); Baltic, composed of Estonia, Latvia, and Lithuania; the West, comprising Belorussia, Moldavia, and the Ukraine; Armenia-Georgia, comprising Armenia and Georgia; and the Muslim SSRs, which are Azerbaijan, Kazakhstan, Kirghizia, Tadzhikistan, Turkmen-

5. We use this year because it is the latest year for which we have data on all of the indicators for which the following comparison is to be made. 
istan, and Uzbekistan. ${ }^{6}$ A slight majority of the population, 51.6 percent, lived in the RSFSR. Only about 3 percent of the population lived in the Baltic or in ArmeniaGeorgia. Another 23 percent lived in the three republics of the Soviet West, and 19 percent lived in the six Muslim republics. Since these groupings exhaust the population of the USSR, the weighted average of the demographic behavior of the parts represents the demographic behavior of the USSR as a whole.

Now let us examine the share of births and deaths that occurred in each region in 1987. We pay particular attention to the shares contributed by the RSFSR and the six Muslim republics. Figure $2 \mathrm{a}$ shows that 45 percent of all births occurred in the RSFSR and 32 percent in the Muslim republics. Figure $2 \mathrm{~b}$ shows that 55 percent of all deaths occurred in the RSFSR, and only 14 percent in the Muslim republics. Figure $2 \mathrm{c}$ shows that while 34 percent of all infant deaths occurred in the RSFSR, 51 percent occurred in the Muslim republics. Finally, Figure 2d shows that while 35 percent of the natural increase - births minus deaths-occurred in the RSFSR, 50 percent occurred in the Muslim republics.

The shares contributed by each of the population subgroups vary greatly from one demographic indicator to the next because of differences between the subgroups in fertility, mortality, and age structure. The shares of demographic events for the Muslim republics differ from their share for the Soviet population because the Muslim republics have high fertility, high infant mortality, and a young population compared to the rest of the Soviet Union.

6. This is a conventional grouping of the Soviet republics, except for our placing of Azerbaijan with the other Muslim republics rather than with the two other Transcaucasian republics of Armenia and Georgia.
This illustrates some of the risks in describing Soviet demographic behavior. Is fertility in the Soviet Union high or low? Answer: Both. It is low in the non-Muslim republics and very high in the Muslim republics. Is the Soviet population growing rapidly or slowly? Answer: Both. It is growing rapidly in the Muslim republics, at 2.0 percent per year, and slowly in the non-Muslim republics at less than 1 percent per year.

Therefore, when one speaks of Soviet demographic behavior, one is speaking of an average of behaviors that differ greatly across regions and ethnic groups. This average reflects the behavior of some of the parts better than others, depending on the demographic indicator referred to. Moreover, the average does not necessarily mainly reflect the behavior of the largest ethnic segments of the population, such as Russians or the Slavic groups taken together.

\section{Ethnic components of \\ Soviet demographic behavior}

Data for Soviet regions are an imperfect surrogate for data on ethnic groups. Fortunately, for some demographic indicators we have direct data on ethnic groups. All Soviet citizens have a nationality (in Russian, natsional'nost').' After they receive their internal passport at age 16, Soviet citizens have an official nationality, which is listed on their identity papers, employment records, military records, and so forth. It is difficult or impossible for an individual to change this official national-

7. For a discussion of the terminology used in Soviet statistics on ethnic groups, see Brian D. Silver, "The Ethnic and Language Dimensions in Russian and Soviet Censuses," in Research Guide to the Russian and Soviet Censuses, ed. Ralph S. Clem (Ithaca, NY: Cornell University Press, 1986), pp. 70-97. 

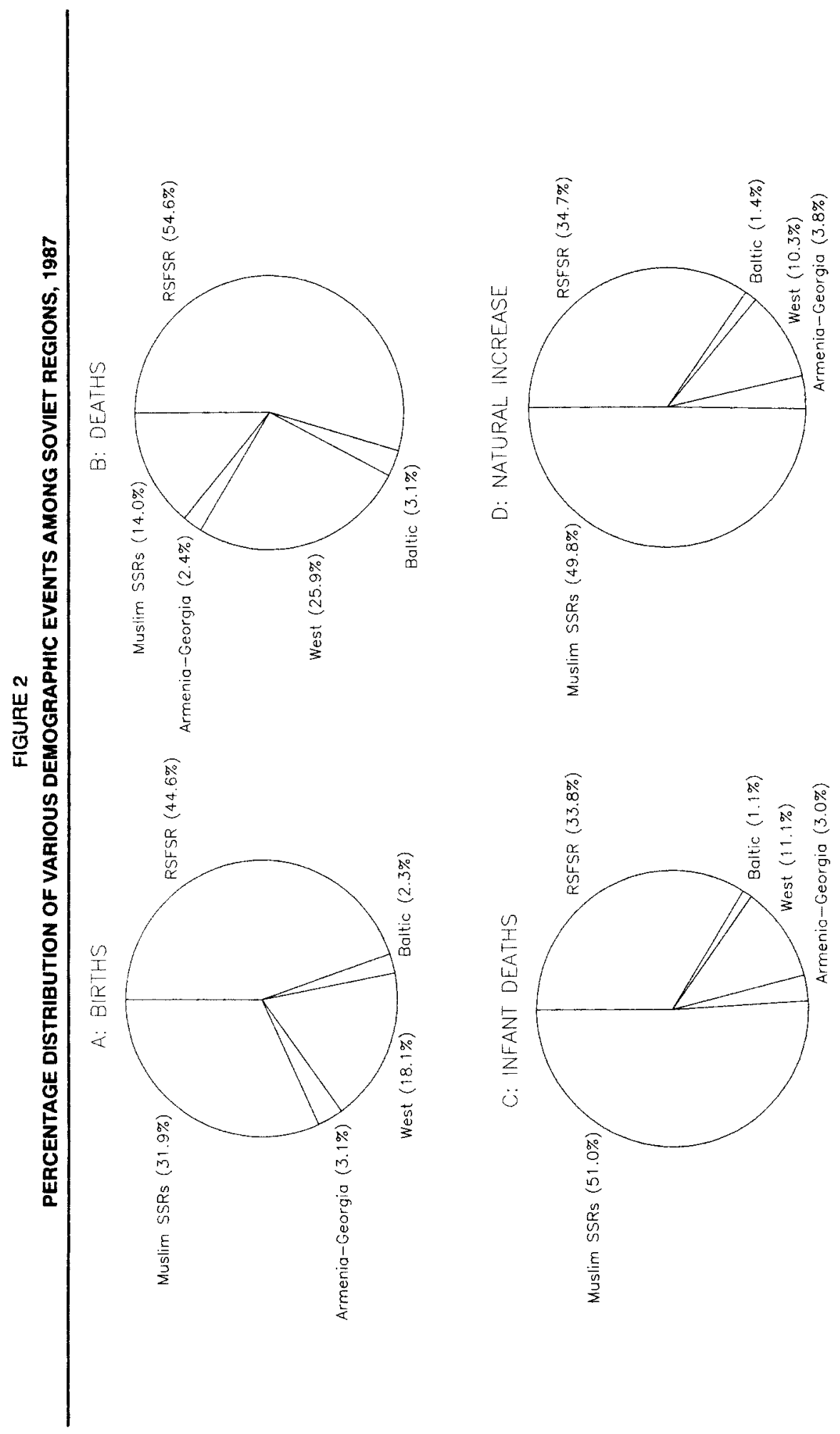
FIGURE 3

PERCENTAGE DISTRIBUTION OF THE SOVIET POPULATION AMONG NATIONALITY GROUPINGS, 1989

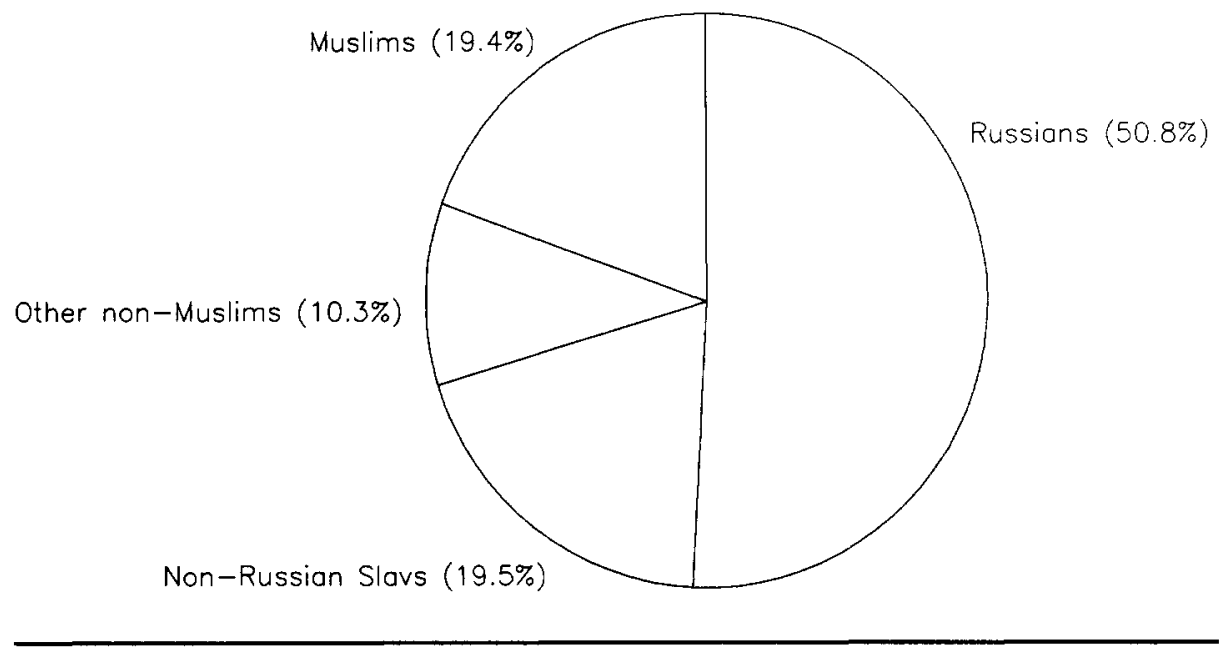

ity. Nationality in the Soviet censuses, however, is a subjective phenomenon, based on the self-report of the individual.

Even if there were no emigration from the Soviet Union, ethnic groups would not be closed populations, since people can migrate into or out of a given nationality by changing their self-reported ethnic identity from one census to the next. We refer to this process as ethnic reidentification. There is evidence of substantial ethnic reidentification among Soviet non-Russian nationalities in the past. ${ }^{8}$

Change in the number of people belonging to the different Soviet nationalities is

8. For a summary of the evidence, as well as a discussion of methods of measuring ethnic reidentification, see Barbara A. Anderson, "Some Factors Related to Ethnic Reidentification in the Russian Republic," in Soviet Nationality Policies and Practices (New York: Praeger, 1978), pp. 309-33; Barbara A. Anderson and Brian D. Silver, "Estimating Russification of Ethnic Identity among Non-Russians in the USSR," Demography, 20:461-89 (Nov. 1983). therefore not simply a result of fertility, mortality, and international migration. Based on projections of the population in 1989 from earlier data, whether ethnic Russians remained a majority of the population of the USSR in 1989 depended substantially on the extent of ethnic reidentification of the population between the censuses of 1979 and 1989. Some people who identified as a member of a nonRussian nationality in 1979 could have called themselves Russian in 1989, and some who identified as Russian in 1979 could have identified with a non-Russian nationality in $1989 .{ }^{9}$

Figure 3 shows the share of the population that belonged to four groupings of Soviet nationalities, according to preliminary data from the 1989 Soviet census: Russians constituted 50.8 percent; nonRussian Slavs, 19.5 percent; other non-

9. For further discussion, see Anderson and Silver, "Demographic Sources." 
Muslims, 10.3 percent; and Muslims, 19.4 percent. The number of people that this represents is given in panel A of Table 2 . These figures are based on the entire Soviet population, not only the titular nationalities of the 15 union republics. ${ }^{10}$

In 1989, Russians remained a bare majority of the Soviet population. We think the number of Russians is somewhat smaller than might have been expected, due to a decrease in the tendency of nonRussians to change their identification to Russian and perhaps to a return by some self-declared Russians to an earlier nonRussian ethnic identity. But with the available data, we cannot measure the extent of ethnic reidentification between 1979 and 1989. ${ }^{11}$

Panel B of Table 2 shows that Russians compose a decreasing share of the Soviet population between the last four census dates, from 54.7 percent in 1959 to 50.8 percent in 1989. Muslims, on the other hand, constitute an increasing share, from 11.8 percent in 1959 to 19.4 percent in 1989. Non-Russian Slavs decreased their share from 22.5 percent to 19.5 percent, while other non-Muslims decreased from 11.0 percent to 10.3 percent. All four groupings, however, grew in absolute size in each intercensal period.

Panel D of Table 2 shows how much each of the four groupings of nationalities contributed to the overall population growth of the Soviet Union between the

10. The Muslim population of the USSR, for example, consists of - in addition to the titular nationalities of the six Muslim SSRs - the Volga Tatars, with 6.6 million people in 1989; the Peoples of Dagestan, with 2.1 million; the Chechens, with 1.0 million; and 21 more Muslim nationalities.

11. Estimation of the amount of ethnic reidentification requires data on the age distribution of the population by nationality. To date-Dec. 1989- no data on age by nationality have been published for either the 1979 or 1989 Soviet censuses. last four census dates. Most noticeable are the relative contributions of Muslims and Russians. Between 1959 and 1970 Muslims contributed 31.7 percent of the population growth of the USSR and Russians contributed 45.4 percent, but by 1979-89 this contribution had reversed: Muslims contributed 49.7 percent and Russians, 32.6 percent. This reversal reflects the continuing high fertility rates of Muslim nationalities and the low fertility rates of Russians, other Slavs, and other non-Muslims.

The differences in the growth rates of nationalities underlie the differences in the natural increase of Soviet regional populations depicted in Figure 2d. ${ }^{12}$ But a comparison of growth rates by region and by nationality - compare panel $\mathrm{C}$ of Table 2 with panel C of Table 3-also makes clear that use of regional data in place of ethnic group data often reduces the magnitude of the differences in demographic behavior. ${ }^{13}$ In the period 1979-89, for example, the Muslim population grew at an average annual rate of 2.4 percent, while the population of the six Muslim republics grew at an annual rate of 2.0 percent. Similarly, the number of Russians grew at an average annual rate of 0.5 percent, while the population of the RSFSR grew at a rate of 0.7 percent. The regional difference is smaller

12. In Figure 2d, we are able to depict rates of natural increase - births minus deaths - by region, because birth and death rates are reported for SSRs. In Table 2, we are not able to depict rates of natural increase of ethnic groups because birth and death rates are not reported for nationalities. But the growth rates given in the table's panel $\mathrm{C}$ closely approximate the rates of natural increase, since only a few nationalities have experienced substantial international migration in recent decades.

13. For further illustrations of this general point, see Brian D. Silver, "Levels of Sociocultural Development among Soviet Nationalities: A Partial Test of the Equalization Hypothesis," American Political Science Review, 68:1618-37 (Dec. 1974). 


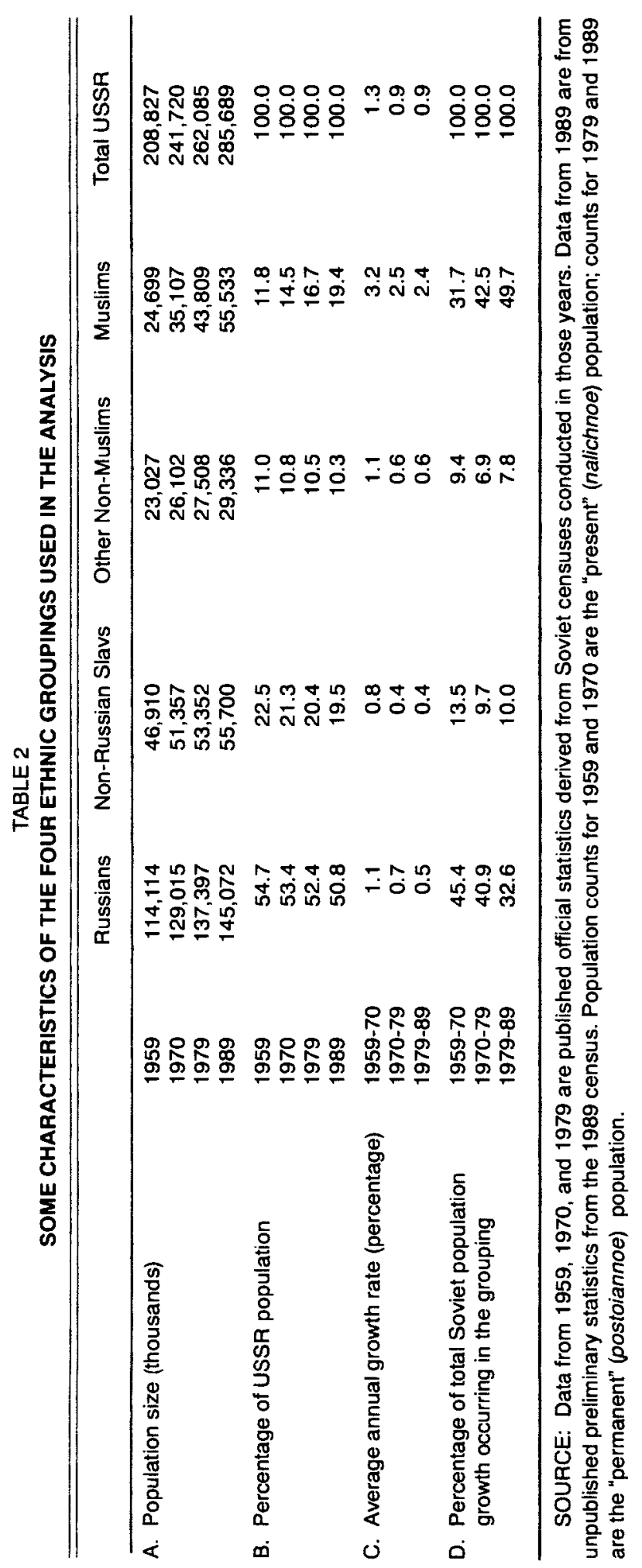




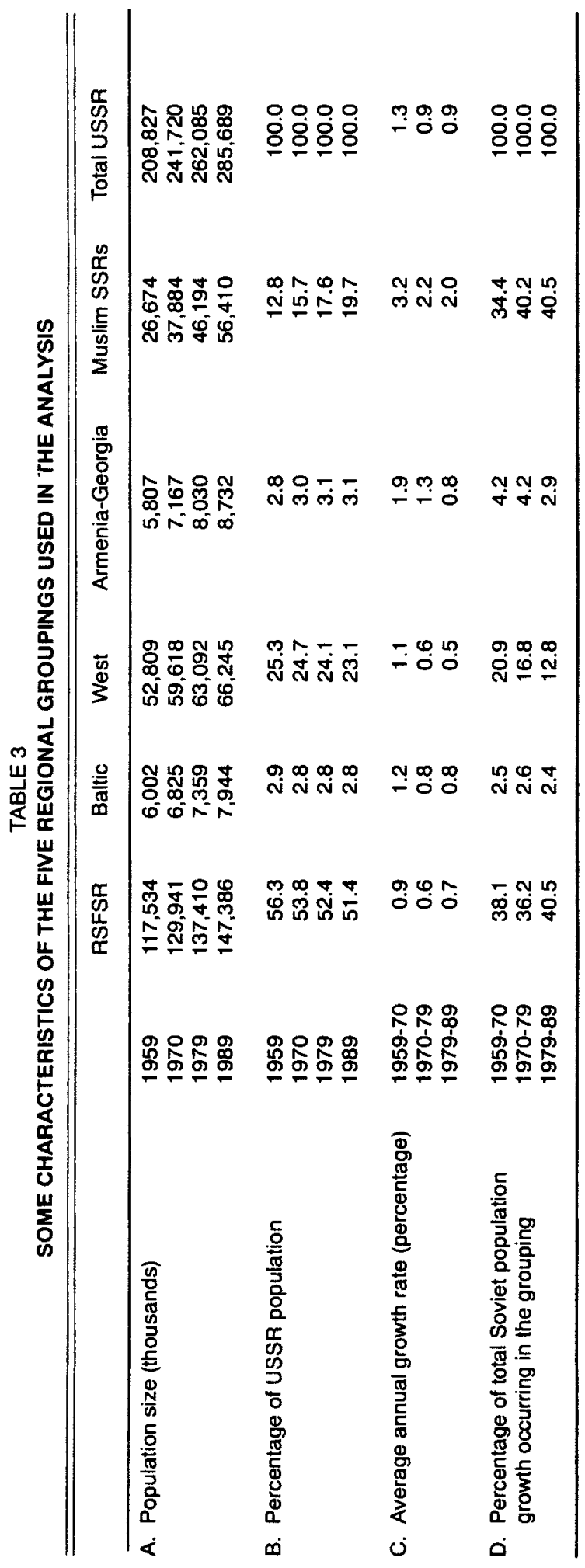


FIGURE 4

ESTIMATED RATES OF NET INTERCENSAL IN-MIGRATION OF RUSSIANS TO REGIONS, 1959-89

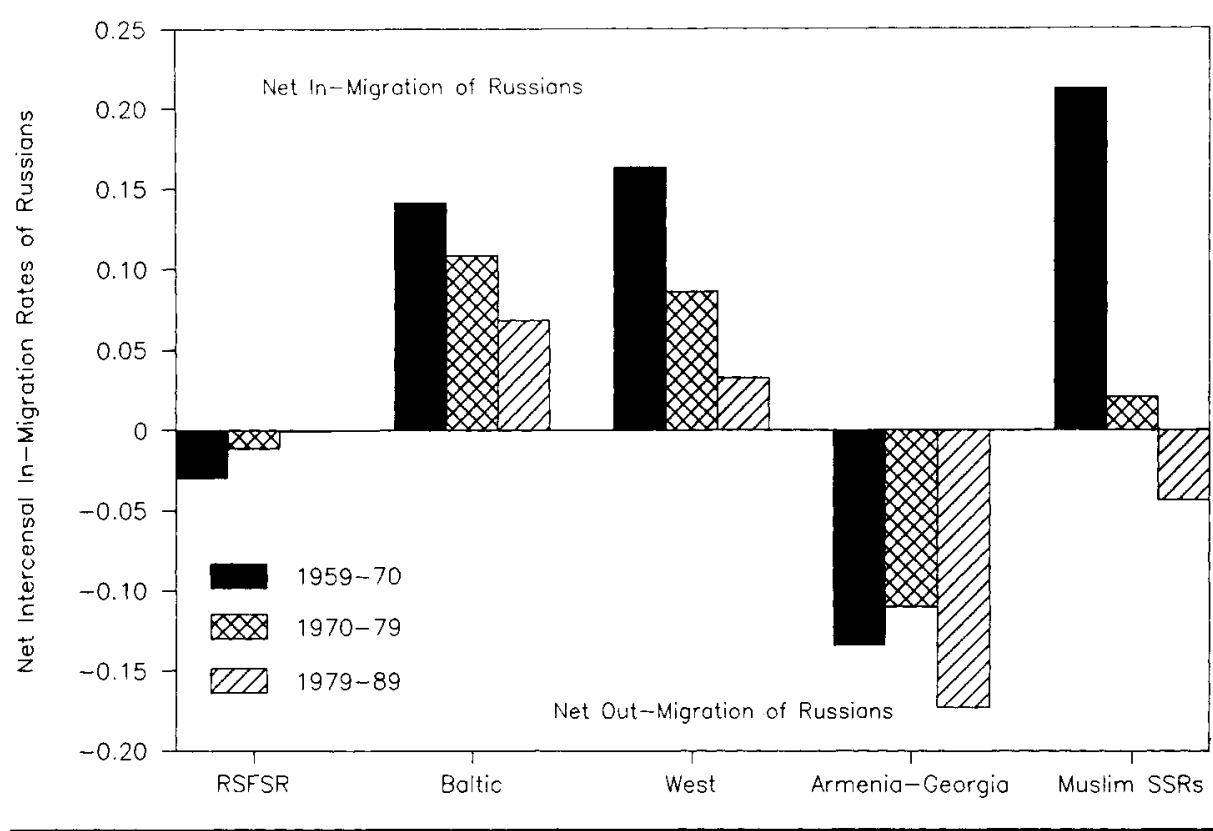

NOTE: This figure shows the estimated amount of Russian net in-migration to the region between censuses divided by the number of Russians in the region at the first census.

than the ethnic group difference because regions are not ethnically homogeneous and because of different migration patterns by ethnic group. In particular, between 1979 and 1989, on balance, Russians migrated out of the Muslim republics and the net migration of Russians out of the RSFSR was close to zero.

Figure 4 shows the estimated net number of Russian migrants into each region between recent census dates divided by the number of persons in the region at the initial date. Thus it shows the proportion by which the population of the region would have increased or decreased in the period due to the migration of Russians. ${ }^{14}$

14. Russians experienced very little international migration. Thus their growth in the Soviet Union as a whole is primarily the result of natural increase. The
We can refer to this as a net migration rate. ${ }^{15}$

Between 1959 and 1970, as well as between 1970 and 1979, there was net migration of Russians into the Muslim republics. Most of this migration was to the Virgin Lands territory of Kazakhstan, ${ }^{16}$ but there

net number of Russian migrants into a region was estimated as the difference between the number of Russians in the region at the second date and the number of Russians there would have been in the region if the Russian population had grown between censuses proportionately to the Russian population in the entire Soviet Union. For more discussion of these estimates, see Anderson and Silver, "Demographic Sources."

15. Strictly speaking, there can be no net migration rate because there is no population at risk of net migration; however, such a measure is conventionally referred to as a net migration rate.

16. In 1959-70, an estimated 69 percent of the net Russian migration to the Muslim republics was to 
was a net influx of Russians into five of the six Muslim republics in both the 1959-70 and 1970-79 intercensal periods - the exception was Azerbaijan, from which there was net out-migration of Russians in both periods. Between 1979 and 1989, however, there was net out-migration of Russians from all six Muslim republics. ${ }^{17}$

Figure 4 also shows that there was net out-migration of Russians from Armenia and Georgia in all three intercensal periods as well as net in-migration of Russians to both the Baltic and the Soviet West in all three periods. Russians were not the only internal migrants; however, Russians, Ukrainians, and Belorussians composed the bulk of those Soviet citizens who moved across union-republic boundaries in response to new jobs.

In the 1950s and 1960s, a policy of the intermixing of different nationalities was endorsed openly by central authorities, and relocation of labor was one method of achieving such mixing. This policy has long been controversial in the non-Russian republics. The net result of the migration patterns by different ethnic groups in recent decades has been the increasing ethnic homogenization and, one might say, indigenization, of the Muslim republics, Armenia, and Georgia, and the decreasing homogenization - increasing Russianization - of the Baltic and the Soviet West. In September 1989, the Central Committee of the Communist Party of the Soviet Union for the first time formally acknowledged

Kazakhstan; in 1970-79, an estimated 44 percent of the net Russian migration to these republics was to Kazakhstan.

17. For further details on the ethnic patterns of migration, see Brian D. Silver, "Population Redistribution and the Ethnic Balance in Transcaucasia," in Nationalism and Social Change in Transcaucasia, ed. Ronald G. Suny (Ann Arbor: University of Michigan Press, 1983), pp. 376-96; Anderson and Silver, "Demographic Sources." the adverse consequences of this policy in particular, its threat to the preservation of ethnic distinctiveness and its exacerbation of interethnic tensions. ${ }^{18}$

\section{DIFFERENCES IN REGIONAL AND \\ ETHNIC DEMOGRAPHIC PATTERNS}

In the remainder of this article, we explore several dimensions of Soviet demographic behavior by region and by ethnic group. We turn now to infant mortality.

\section{Infant mortality}

The IMR is often interpreted as an indicator of the quality of life in a society. It reflects the effects of personal health and hygiene, diet, public health and sanitation programs, and the quality and availability of medical services. Figure 5 shows the differences in the average IMRs for the republics in each group at five-year intervals from 1960 to 1985 . The IMR for the USSR as a whole in 1985 was about the same as it was in 1965. This contrasts with the trend toward improvement in infant mortality in most other countries of the industrial world.

The data for separate regional groupings show different levels and trends in infant mortality. In the RSFSR and the Baltic, the IMR declined in each five-year interval except 1970-75. In the West also the IMR rose between 1970 and 1975 and was lower in 1985 than in 1960 and 1965 , but between 1965 and 1985 there was little decline. The pattern in Armenia and Georgia is similar to that found in the West, except that the IMR in 1985 was much lower than the IMR in 1965. In general, the patterns of change in the IMRs in the

18. See "Party's Draft Platform on Nationalities Policy," Current Digest of the Soviet Press, 13 Sept. 1989, pp. 1-8. 


\section{FIGURE 5}

\section{INFANT MORTALITY RATE FOR USSR AND SOVIET REGIONS, 1960-85}

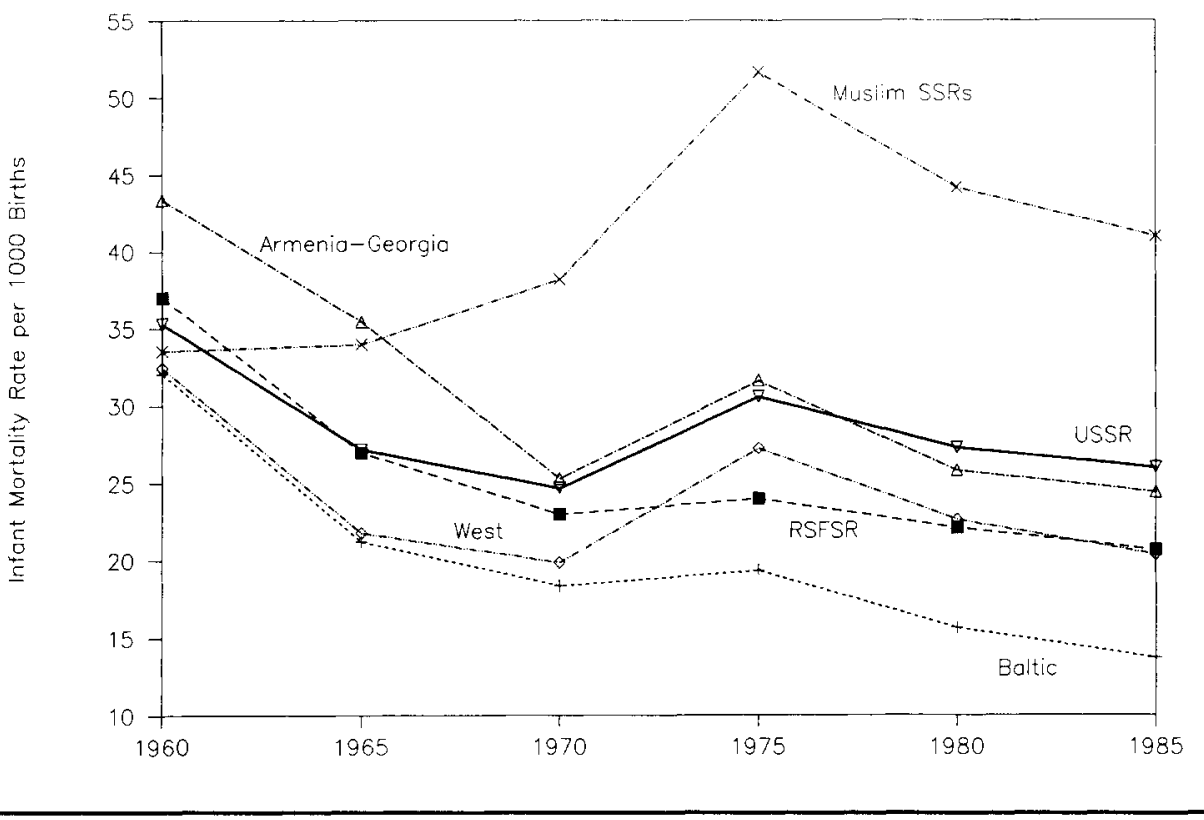

RSFSR, Baltic, West, and ArmeniaGeorgia were similar to one another between 1960 and 1985.

The most distinctive pattern appears in the Muslim republics. There the reported IMR in 1960 was, on average, lower than that found in the USSR as a whole and in the other four regions. It then rose to a peak in the mid-1970s and subsequently declined. The average IMR in 1985, however, was substantially higher than the IMR in 1960,1965 , and 1970, and it was much higher than the IMR in the other Soviet regions.

Why the distinctive pattern among Muslim republics? The figures for 1960 tell part of the story. Medical services, health care, and public sanitation are of lower quality and more limited availability in the Muslim republics, especially those in Central Asia, than in most other regions of the USSR. ${ }^{19}$ That the IMR in 1960 reported for the Muslim republics was lower than the IMRs reported for other regions undoubtedly reflects underreporting of infant deaths in the Muslim republics. This does not mean that all infant deaths were reported in other regions, but the extent of the underreporting was probably much greater in the Muslim areas. ${ }^{20}$ The rise in

19. We have heard reports of IMRs of over 100 for some remote parts of Siberia, within the RSFSR. No IMRs that high have been officially published for any region of the Soviet Union in recent years, however.

20. Elsewhere we estimated the IMRs for the indigenous nationalities of the Muslim republics. We found that in 1959, the IMRs of people belonging to the indigenous nationalities were lower than the IMRs of the European-background population-such as Russians and Ukrainians - living in the Muslim republics. This is implausible. See Barbara A. Anderson, Brian D. Silver, and Jinyun Liu, "Mortality of Ethnic Groups in Soviet Central Asia and Northern 
the IMRs in the Muslim republics in later years probably reflects mostly improvements in the reporting of infant deaths, not worsening actual infant mortality. In other words, the actual IMRs in the Muslim republics in 1960 were probably higher than the rates reported in the mid-1970s and later.

Elsewhere we have argued that the rise in reported infant mortality in the Soviet Union in the early 1970s was mostly an artifact of improvements in statistical record keeping and the completeness of reporting of infant deaths, especially in Soviet Central Asia. Both in Central Asia and elsewhere in the Soviet Union, new procedures introduced in the early 1970 s for tabulating infant deaths, along with increasing incentives for registering infants who were at high risk of dying in infancy, could have raised the reported IMRs even if the actual IMRs remained the same or declined. ${ }^{21}$ We think these new procedures and incentives would have had this effect not only in the Muslim republics but also in other parts of the Soviet Union.

This does not mean that all increases in mortality reported in the 1960s and 1970s in the Soviet Union were an artifact of improved reporting. The increase in reported mortality of working-age males beginning in the mid-1960s probably reflected real worsening of the health of Soviet males. ${ }^{22}$ Moreover, it is possible that

China," Research Reports (University of Michigan, Population Studies Center), Sept. 1989, no. 89-158.

21. See Anderson and Silver, "Infant Mortality in the Soviet Union."

22. For further discussion, see Barbara A. Anderson and Brian D. Silver, "Sex Differentials in Mortality in the Soviet Union: Regional Differences in Length of Working Life in Comparative Perspective," Population Studies, 40:191-214 (July 1986); idem, "Changing Shape"; idem, "Patterns of Cohort Mortality in the Soviet Population," Population and Development Review, 15:471-501 (Sept. 1989). some of the increase in infant mortality was also real. There are many reports, for example, of poor water quality in Central Asia, perhaps intensified by the increasing population density in rural areas.

\section{Fertility rates}

Part of the explanation of the high rates of infant mortality among Soviet Muslim populations may be high fertility. When women have many children, especially in the context of limited availability of prenatal care or limited possibility of using the available services, then newborns are likely to be at high risk of dying. Among some Muslim populations, such as Tadzhiks and Turkmenians, the frequency of marriages between cousins is also a special risk factor for infant mortality.

Figure 6 shows the average total fertility rate (TFR) for the titular nationalities of the five regions of the USSR at three dates, 1958-59, 1969-70, and 1978-79, as reported by Soviet demographers. ${ }^{23}$ The TFR is the number of children that a woman would have in her reproductive life if she followed a given age-specific fertility schedule, such as that of all women in a given year. Figure 6 shows that the TFR of the Muslim groups is much higher than that of the others. On average, as late as 197879 , Muslim women could expect to bear 5.6 children, while non-Muslim women could expect to bear between 1.8 and 2.3 children.

The comparatively low fertility of nonMuslim women is not a result of a high incidence of childlessness; in fact, very high proportions of non-Muslim women marry and have at least one child. High

23. G. Bondarskaia and L. Darskii, "Etnicheskaia differentsiatsiia rozhdaemosti v SSSR" (Ethnic differentiation of fertility in the USSR), Vestnik statistiki, Dec. 1988 , no. 12 , pp. 16-21. 


\section{FIGURE 6}

AVERAGE TOTAL FERTILITY RATE OF TITULAR NATIONALITY IN UNION REPUBLICS WITHIN REGIONS, 1958-79

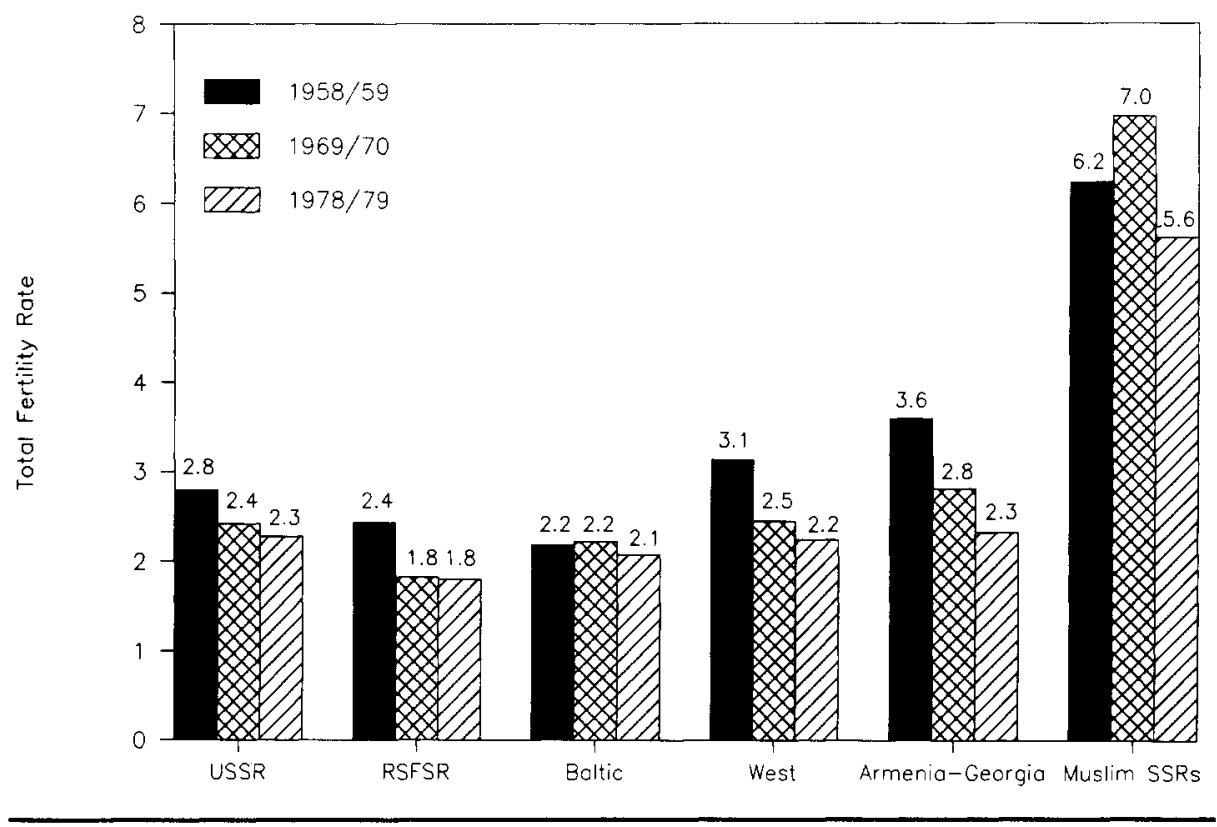

fertility of Soviet Muslim women has persisted despite their high levels of education compared to Muslim women in other countries. For example, in the rural population of Tadzhikistan in 1979, 48 percent of females aged 10 or over had at least seven years of education; and of the six Muslim republics, the population of Tadzhikistan had the lowest level of educational attainment in 1979. In contrast, in Egypt in 1976, only 15 percent of females aged 10 or over had at least primary education.

The rise in the reported TFR among Muslims between 1958-59 and 1969-70 was probably the result of a combination of some real increase in fertility and an artifactual increase in fertility resulting from more complete reporting of births. ${ }^{24}$ It has been estimated, for example, that in Tadzhikistan 23 percent of the births in the latter 1950s were not reported. ${ }^{25} \mathrm{Un}$ -

24. A real increase in fertility between 1959 and 1970 could have occurred as a result of a reduction in the proportion of women of childbearing ages who are married to much older men. See Barbara A. Anderson, "Male Age and Fertility: Results from Ireland prior to 1911," Population Index, 41:561-66 (1974).

25. See Ansley J. Coale, Barbara A. Anderson, and Erna Härm, Human Fertility in Russia since the Nineteenth Century (Princeton, NJ: Princeton University Press, 1979); Anderson and Silver, "Estimating Russification." For indirect evidence of improvement in registration of births, see idem, "The Effects of the Registration System on the Seasonality of Births: The Case of the Soviet Union," Population Studies, 42:303-20 (July 1988). 
derregistration persisted into the $1960 \mathrm{~s}$ and 1970 s but probably diminished in prevalence. ${ }^{26}$

The strong ethnic differences in the TFRs illustrate why the answer to the question, Is fertility in the Soviet Union high or low? is, Both. At the same time, it is clear that the rates are changing. As shown in Figure 6, they declined for all ethnic groupings between 1969-70 and 1978-79. In later years, for which we have data by region but not by ethnic group, the TFRs of Muslim areas continued to decline through the 1980 s, but they rose slightly in the non-Muslim areas. As a result, the TFR of the USSR population in $1986-87$ was 2.51 , compared to 2.27 in $1978-79$.

\section{High-order births}

Another indicator of differences in fertility behavior within the Soviet Union is the prevalence of high-order births. Figure 7 shows the percentage of births that are of fifth or higher order for various years for which data are available for Soviet republics.

If any single measure could testify to the sharp difference in the life situations of women, and the comparative risks of infant mortality between regions and ethnic groups, it is this one. In the 1960s and early 1970 s, more than 30 percent of all births were of fifth or higher order in the Muslim republics. Even in 1986, one of every six

26. Coale, Anderson, and Härm, Human Fertility in Russia; Barbara A. Anderson and Brian D. Silver, "Estimating Census Undercount from SchoolEnroliment Data: An Application to the Soviet Censuses of 1959 and 1970," Demography, 20:461-89 (Nov. 1983); W. Ward Kingkade, An Evaluation of Selected Soviet Population Statistics, CIR Staff Paper no. 9, U.S. Department of Commerce, Bureau of the Census, Center for International Research, Nov, 1985. births in the Muslim republics was fifth order or higher. ${ }^{27}$

The percentage of high-order births has dropped at successive dates in every region, except for the increase between 1965 and 1970 in the Muslim SSRs. This is consistent with the pattern of change in the TFRs during the same time span.

\section{Distribution by age}

A major consequence of the differences in fertility between regions and ethnic groups is differences in the age distributions of the population as well as differences in the growth of segments of the age structure. Of special interest is the size of the working-age population, as well as the population below and above the working ages. By convention in Soviet labor statistics, the working ages are 16-59 for men and 16-54 for women, although this does not mean that all people enter the labor force exactly at age 16 and retire at age 55 or 60 .

Panels A through C of Table 4 show for each regional grouping the number of persons in the three age categories at the time of the censuses of 1959, 1970, and 1979, as well as in 1987, which is not a census year. ${ }^{28}$ The data from these panels are summarized in Figure 8. We use data on regions

27. This measure actually understates the difference between Muslim and non-Muslim fertility, because it does not take into account differences in the age structures of the regional populations. Since the age distribution of women in the Muslim republics is much younger than the age distribution of women in other regions, proportionately fewer Muslim women would be near the end of their childbearing years.

28. The latest date for which age data for the Soviet population have been published is 1987, a noncensus year. Age distributions in Soviet censuses are subject to error caused by undercounting of young children, older adolescents, and young adults, as well 
FIGURE 7

\section{PERCENTAGE OF BIRTHS THAT WERE \\ ORDER FIVE OR HIGHER FOR USSR AND SOVIET REGIONS, 1965-86}

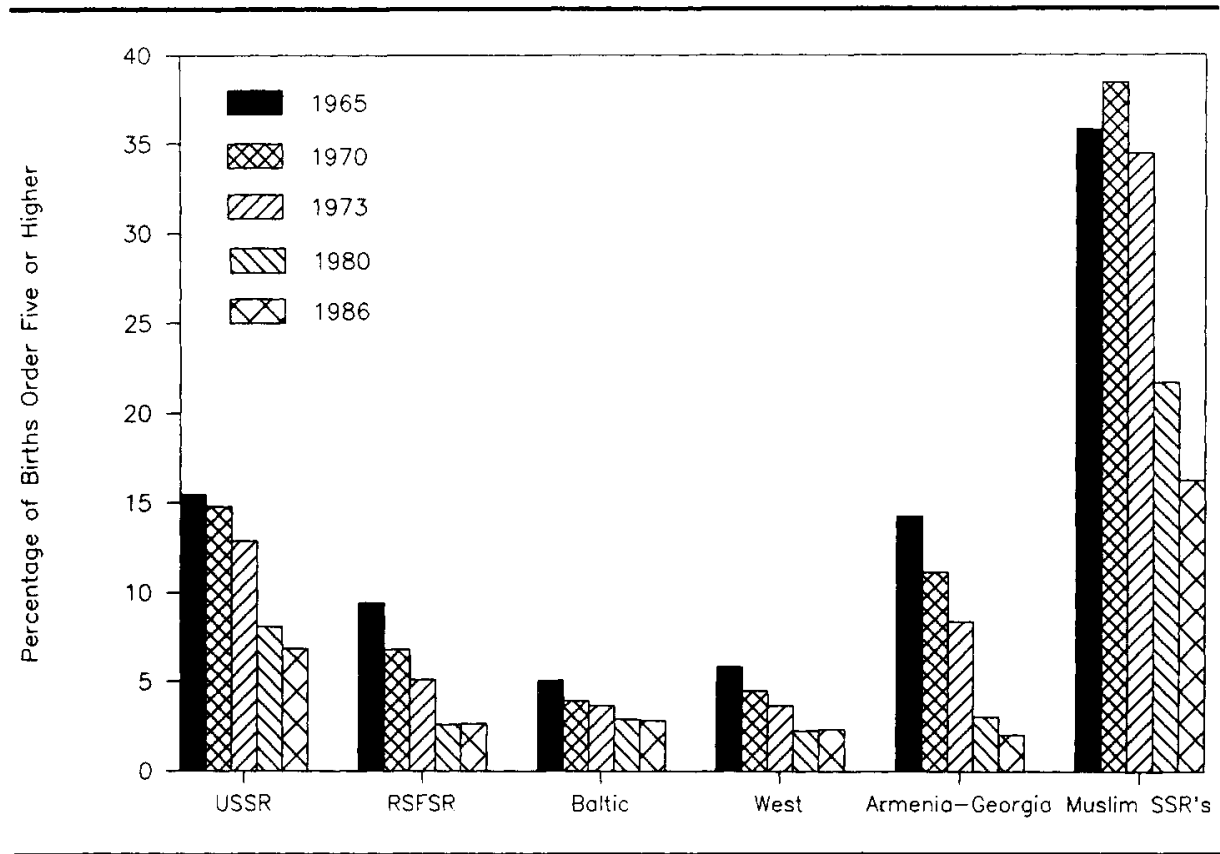

rather than ethnic groups because statistics on the age distributions of ethnic groups have not been published since the 1970 census.

Four of the regions-RSFSR, Baltic, West, and Armenia-Georgia - experienced little change between 1959 and 1987 in the number of persons under the working ages. The dip between 1970 and 1979 in the RSFSR is an echo of the small size of the cohort of women born during World War II, which resulted in a small cohort being born during the 1970s. A similar, though weaker, pattern appears also in the West and the Baltic.

as age misstatement, including age exaggeration, by old people. For further discussion, see Anderson and Silver, "Estimating Census Undercount"; Lea Keil Garson, "The Centenarian Question: Old Age Mortality in the Soviet Union 1897-1970" (Ph.D. diss., Princeton University, 1986). We do not have enough information to correct the age distributions for each region.
In the fifth region - the Muslim SSRs the number of persons below working ages more than doubled between 1959 and 1987, from 10.1 million to 21.1 million. This is not surprising in light of the differentials in fertility observed earlier. Moreover, the Muslim populations of Soviet Central Asia did not suffer losses in World War II as severe as those suffered by the Russians, Balts, Ukrainians, and Belorussians and hence do not show a decline between 1970 and 1979 in the number of people below the working ages. ${ }^{29}$

All of the regions experienced growth in the number of persons in the working

29. For further discussion of the demographic impact of World War II on Soviet nationalities, see Barbara A. Anderson and Brian D. Silver, "Demographic Consequences of World War II on the NonRussian Nationalities of the USSR," in The Impact of World War II on the Soviet Union (Totowa, NJ: Rowman \& Allanheld, 1985), pp. 207-42; idem, "Patterns of Cohort Mortality in the Soviet Population." 


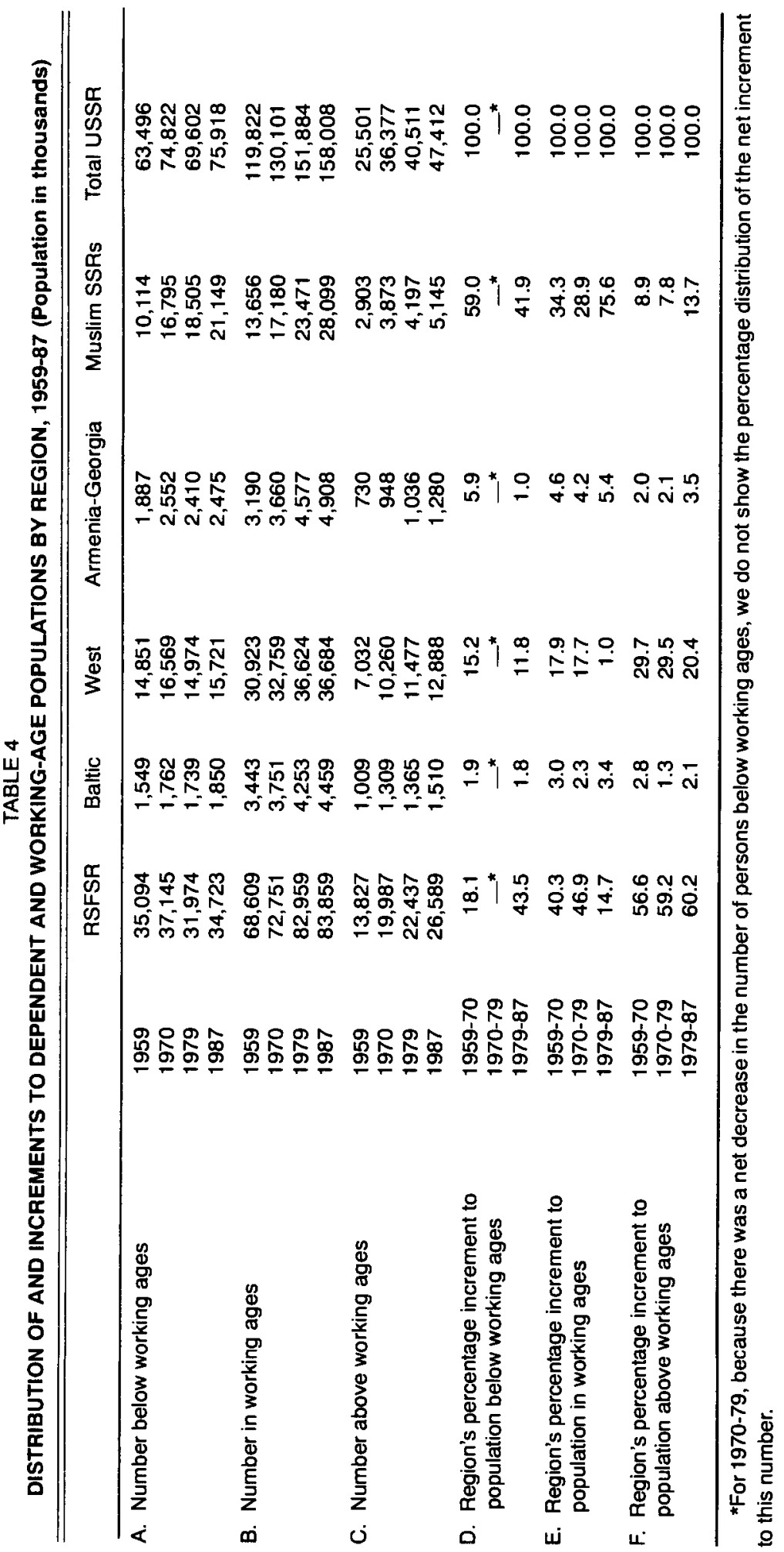


FIGURE 8

POPULATION BELOW WORKING AGES, IN WORKING AGES, AND ABOVE WORKING AGES FOR SOVIET REGIONS, 1959-87

A: Population Below Working Ages
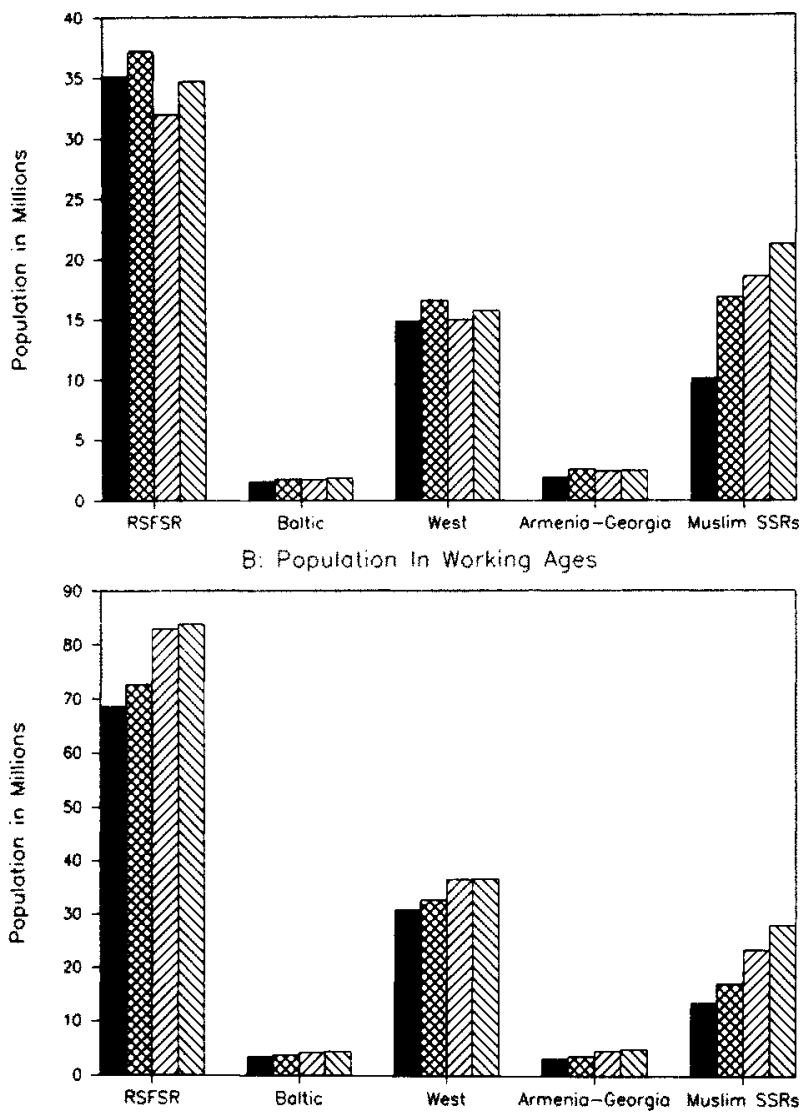

G: Poputation Above Working Ages

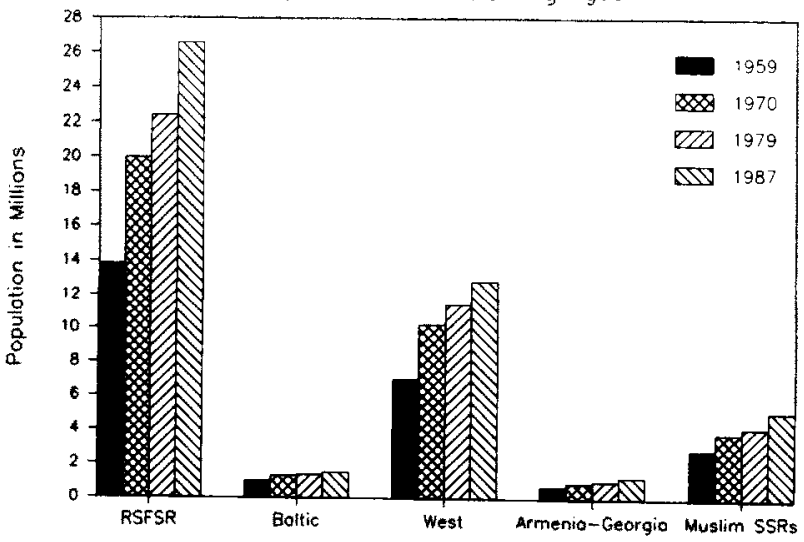


ages in each interval. The largest absolute growth occurred in the RSFSR $-15.2 \mathrm{mil}$ lion. The sharpest rise in the RSFSR occurred between 1970 and 1979 . The increase in population in the working ages in the Muslim republics between 1959 and 1987-14.4 million - nearly equaled that of the RSFSR. In relative terms, the growth of the working-age population in the Muslim republics - 105.8 percent-far outstripped the growth in the RSFSR 22.2 percent.

Every region experienced growth in the number of persons above the working ages. In both absolute and relative terms, the largest increase -12.8 million, or 92.3 percent-occurred in the RSFSR. But the relative growth was quite substantial in all regions except the Baltic. Even in the Muslim republics the number of persons above working age increased by 77.2 percent between 1959 and 1987. The growth of this number in the Baltic was probably held down by the fact that its population was relatively old even in 1959 .

The Muslim republics are the only region to experience substantial growth in all three age segments between 1959 and 1987. As a result, they are becoming an increasingly large contributor to the net increments to the Soviet population in the working ages and above the working ages. As shown in panel E of Table 4, in the 1959-70 and 1970-79 intercensal periods, the Muslim SSRs contributed about a third of the net additions to the working-age population of the USSR. Between 1979 and 1987, however, the Muslim SSRs contributed three-fourths of the net increment to the working-age population of the USSR.

This does not mean that three of every four workers first entering the labor force comes from a Muslim republic. Only about one-fourth of new entrants to the working ages between 1979 and 1987 lived in a Muslim republic. ${ }^{30}$ The net increment to the working ages from a given region is the difference between the number of people in that region entering the working ages and the number leaving the working ages, whether through reaching pension age or through death. The relatively young age composition of the populations of the Muslim republics means that they account for a very substantial share of the new entrants plus survivors in the working ages, even larger than their contribution of 50 percent of the net increment to the Soviet population as a whole between 1979 and 1989.

Another source of the increasing contribution of the Muslim republics to the working ages and to the population over the working ages is high and increasing adult male mortality in the European part of the USSR, especially between age 40 and 60 . Adult male mortality was especially high in the RSFSR. In 1969-70, a male in the RSFSR who had survived to age 40 had only a 75 percent chance of surviving to age 60. In Soviet Central Asia and Transcaucasia, a 40-year-old man in 1969-70 had an 86 percent chance of living to age 60 . The level of adult male mortality in the RSFSR in 1969-70 was higher than in any other developed country. In 1985-86, the chance that a 40-year-old male in the RSFSR would live to his sixtieth birthday was still only 75 percent; however, the earlier worsening of adult male mortality in the RSFSR had stopped.

In contrast, in 1985-86 males in Armenia experienced the lowest mortality of any republic population in the 40-60 age range. In that year, a 40-year-old male in Armenia

30. Recall that, as shown in Figure 2a, only 32 percent of births in 1987 occurred in the Muslim republics. Moreover, only 25 percent of the $15-$ to 19-year-olds in 1987 resided in the Muslim republics. 
had an 86 percent chance of living to age 60. The reported mortality in Armenia for adult males between the ages of 40 and 60 was comparable to that in the Federal Republic of Germany in 1981-82 or Japan in 1969-70, although it was lower than that of American men in 1981-82. ${ }^{31}$

\section{CONCLUSION}

One lesson from this analysis is that the study of Soviet demographic behavior requires sensitivity to differences in behavior between regions and ethnic groups. These differences must be an important aspect of any attempt to explain the trends in the behavior and composition of the Soviet population.

The ethnic differentials in rates of population growth that we have shown make clear why so many issues in social policy in the Soviet Union have different implications for different ethnic groups. Pronatalist policies in the USSR, aimed primarily at the non-Muslim groups, exist alongside programs to reduce fertility among Muslim women. School enrollments are holding steady or increasing moderately in much of the USSR but growing rapidly in the Muslim areas. Increasing shares of conscripts to the armed forces and of new entrants to the labor force come from the Muslim populations; decreasing shares come from Russians and other nonMuslims.

Furthermore, a majority of the net increment to the labor force comes from the

31. For further discussion, see Anderson and Silver, "Sex Differentials"; idem, "Changing Shape." The Central Asian republics report fairly low adult male mortality. We think that this is partially a result of underreporting of mortality and overstatement of age in Central Asia. See Anderson and Silver, "Changing Shape."
Muslim republics. This presents certain problems for the development of the Soviet economy. The main problem is not the education and skill levels of population from these republics. New entrants to the working ages from the Muslim republics are probably, on average, better educated than the workers who are leaving the labor force through retirement or death. Instead, the problems relate to the location and mobility of the indigenous populations of the Muslim SSRs. The populations show little inclination to move from their traditional regions of settlement to areas that are experiencing labor shortages, and they usually have poor command of the Russian language and hence cannot move to just any job for which their technical or other skills qualify them. Moreover, since nonindigenous populations seem to be departing from the Muslim republics, there is even less incentive for the members of the titular nationality to leave their home republic in search of work or career opportunities or to improve their facility in the Russian language.

The changing ethnic composition of Soviet regions - toward greater Russianization of the European republics and greater indigenization of the non-European ones - is also important for understanding the ethnic politics of the Soviet Union. In the Baltic republics and Moldavia, leaders of the Communist Party and of popularfront movements have sought to limit the in-migration of Russians in order to preserve the culture and language of the titular nationality and to assert greater local control over the future economic and political development of their republics. If the policy of economic and political perestroika ("restructuring") continues to evolve toward greater local autonomy, then these 
non-Russian republics are likely to become less hospitable to in-migrants from nontitular nationalities than they have been in the past. In most non-European republics, outmigration of Russians and other non- indigenous nationalities was under way well before Mikhail Gorbachev came to power in 1985. Further implementation of perestroika is likely to help sustain that tendency. 